\title{
Assessing the Implementation of Decentralized Management System: Babre Tabor Municipality Administration in Focus
}

\author{
Belaynew Mesfin Demelash \\ Lecturer in Bahir Dar College of Polytechnic, Amhara Regional State, Ethiopia
}

\begin{abstract}
This study addressed the efforts exerted on the implementation of decentralization management system employed a few years ago in a governmental institution. More specifically, this study attempted to assess the perceptions employees hold about the decentralization package, their decision-making practices and correlations among participants' perception, decision-making practices and provision of resources. To this end, of one Hundred employees, fifty participants of Debre Tabore Muncipality administrative, in Amhara regional state, were selected in a mix of systematic and stratified sampling technique. A likert scale and frequency count itemized questionnaire was administered and forty-eight questionnaire was returned filled in. The major findings showed that participants had a reasonable level of awareness on the positive roles of decentralization, considerable level of decision-making practices and some degree of perceived provisions of resources or support. Besides, there seemed to have positive relationships among the participants' perceptions about municipality decentralization, input provision and practice of decision making. small but positive correlations among perceptions. A mere degree of variations of responses to the perceptions and practices of decentralization were also seen due to background differences in gender, position and work experiences. In light of the results, the decentralization could be implemented with a more focus of employees concern on resource provisions and shared commitment.
\end{abstract}

Keywords: decentralization, decision-making practices, perceptions

DOI: $10.7176 / \mathrm{JESD} / 13-3-03$

Publication date: February $28^{\text {th }} 2022$

\section{Background of the Study}

The idea of decentralization was first introduced in governance in the 1950s and 60s by Britain and France for sharing powers to local states of their colonized nations (Gaule, 2010). The author noted that this form of decentralization was mainly focusing on empowering local states of administrative responsibilities. Besides, a more extended form of decentralization was implemented in western world in the 1980s mainly for economic planning and management. Recently, this concept of decentralization has become a worldwide political and management means in both governmental and nongovernmental roles (Ibid).

According to Jamo (2005), decentralization refers to a way of transferring decision making authority or power to lower management and/or administrative bodies closer to the public. Jamo notes that the concept of decentralization has been discussed with four dimensions: political, administrative, fiscal, and economic/market. He states a political decentralization mainly focuses on providing citizens or elected representatives more power of public decision making. Administrative decentralization concerned with distributing decision making authorities of managing human resource, material and financial resources for public services (Adjei, 2007). Fiscal decentralization, on the other hand, emphasizes on transferring power of controlling resources from central to lower governing bodies; economic/market decentralization mainly addresses shift of responsibilities from the public or government to private sector (Ibid). Generally, with its various dimensions, decentralization involves sharing decision making responsibilities or powers to the lower management/administrative agents who are closer to the public or stakeholders.

Decentralization can be made in three ways. First, decentralization in the form of deconcentration that transfer of power is made by reallocating officers from central to regions or districts. This form of decentralization, as Bergh (2004), notes, does not bring more participation from lower public agents. Secondly, decentralization as a form of devolution that sharing of decision making power and authority is made between national and regional states with legally defined principles and roles (Robertson, 2002). The last, but not the least form of decentralization is delegation; it involves transfer of authorities and responsibilities from the central government to semi-autonomous agents for planning and managing government activities run by the central government (Adjei, 2007). Generally, in the process of decentralization elements such as authority, autonomy, accountability and capacity are decisive variables usually considered in implementation of decentralization program (USIAD, 2009).

According to Robertson (2002), decentralization governance is recommended mainly for addressing problems of inefficiency of administration, macroeconomic instability and ineffective resources management and utilization. Solomon (2008) also notes, decentralization motivates localities for using their own knowledge and customs in the development process. Decentralization as means of political and managerial administration, Bergh (2004) states the following functions:

Reasons for decentralization among other things is to create proximity between the political 
representatives and citizens and therefore facilitates better mobilization and allocation of resources, more creative, innovative and responsive programmes which allow local experimentation and provides better opportunities for local residence to participate in decision making $\quad$ (2004:12).

According to the author, decentralization creates conducive managerial and administrative atmosphere for effective human, material and financial resource management and utilization for bringing about desired socioeconomic development in general and improvement of public service delivery in particular.

However, such positive roles of decentralization entertain some forms of criticism that authorized local administrative individuals may abuse their power for mismanagement of resources and proliferation of corrupted behaviors and acts (Crook and Manor 1998). In other words, the authors note narrow minded nationalists may use such structure of autonomy for their own personal privileges by neglecting the local community's participation and legal rights for managing and using the existing resources. Nevertheless, decentralization becomes a better option if it is implemented successfully. According to Gaulle (2010: 48), "successful public governance decentralization results in performance growth, compliance with the needs of the society and democratic development". Thus, decentralization in public governance or any kind of municipality administration has been used for effectively addressing administrative and managerial needs of citizens.

In municipality decentralization, Ostaaijen (2008: ) notes the idea of intra decentralization referring to the combination of decentralization and democratization for building strong relationship and interaction between municipal administrative bodies and citizens through improving decision making bodies and institutions at lower levels. According to the author, municipal decentralization in such context granted authority within a defined territory, responsible for lots of public tasks, taking aspects of political decision making bodies, responsible for service provision, merely independent to local authority but responsible for it.

According to Tegegne Gebre-Egzibher (2004), in Ethiopia decentralization has two phases of progression. The first phase of decentralization (1991-2001), as the writer noted, has shaped the central political system into federally structured administration regions, and focused on ensuring regional states' authorities and responsibilities of self-administration. The second wave of decentralization which was initiated in 2001 primarily focused on empowering local administrative units or weredas for managing and controlling their own resources through District Level Decentralization Program (DLDP) and Urban Management Program (UMP) (Ibid).

Hence, according to Gulyaniet al (2001), municipality decentralization in Ethiopia has become a recent phenomenon despite the federalized government with constitutionally decentralized regional states established more than two decades back. The authors also noted municipality roles in general and decentralized municipalities' functions in particular seem to be ambiguous and inconsistent:

The institutional framework in which municipalities currently function is complex, ambiguously defined at all levels of government, and inconsistent across regions... the role of municipalities in the decentralization efforts is particularly unclear. Even the Regional Affairs Department in the Office of the Prime Minister, which has substantial overall responsibility for the decentralization process, has no formal link to municipalities. Gulyani et al (2001:12)

Although decentralization in municipality governance brings more opportunities to community based participation and decision making in planning, implementing and monitoring municipal functions and tasks (Robertson, 2002; Solomon, 2008), a clear understanding of granted authorities and responsibilities and high level of commitment seem to be required from the governing bodies and stakeholders for effective implementation. This study, thus, focuses on assessing whether Debre Tabor decentralized municipality (one of the Amhara region urban centers) implemented in the way it is intended.

The role of decentralization in effective municipal governance has been well acknowledged in developed and developing countries, and they have been using it since 1980s (Gaule, 2010). In Europe, for example, an assessment was conducted on the implementation of municipal decentralization in three cities such as Bologna, Rotterdam and Birmingham (Ostaaijen 2008). Using an evaluation criteria like localization (accessibility of services to local community, flexibility of making managerial and administrative decisions, devolution of power for making decisions on service delivery, and organizational change of culture for participatory decision making), the implementation performance of the three cities has been evaluated(Ibid). The assessment result indicated that Bologna city of Italy became the best exemplary for proper functioning of decentralized municipal governance. The city had well established structure and comprehensive channels that discharged municipal services independently and efficiently.

In African context, an assessment of municipal decentralization implementation was also conducted in Tanzania with Morogoro municipality council (Lambeck, 2011). The study focused on one variable i.e, localization which includes physical accessibility and openness of services delivery. Using questionnaire, in-depthinterviews, focus group discussion and observation for data collection, the researcher concluded that the municipality decentralization was not effective in addressing the intended services. However, in Ethiopian context, few attempts have been made on implementation assessment of decentralization process in municipal 
administration though considerable number of research works have been done on decentralization of national political, administrative and fiscal areas (e.g., Oxfam GB, 2005; Tegenu, Tsegaye, 2006; Yimer, Muhammed Seid, 2006; Merera Gudina, 2007; Negussie, Solomon (2008), Mulugeta Debebe Gemechu, 2012). Most of the studies' reports tend to emphasize the major barriers observed in the decentralization process of political, administrative and fiscal of the country in term of granting power authority to the local governing bodies, free from central government interferences, get professional and committed manpower recruited based on meritocracy and democratically elected leaders.

Concerning decentralized municipality experience, Adony Habtu (2011) attempted to assess public participation in "decentralized governance in Adi-Haki local administration in Mekelle City". Using questionnaire and interview for data collection, the study report emphasized the ineffective means of involving citizens in the decision process of service delivery though mere instances of consultation were made between authorities and some community representatives. Mbedzi and Gondo (2010) also evaluated the efficiency and effectiveness of fiscal decentralization in revenue collection and management at Dangila Municipality located some 80 kilo meters away from Bahir Dar City, the seat of the Amhara regional state. The study used financial documents and questionnaire to obtain data, and the research indicated poor efficiency and effectiveness of revenue collection and expenditure mainly for poor organizational structure, working guidelines, planning skills and lack of awareness on tax payers. A recent assessment by Atlaw and Mohammed (2014) on the effect of urban municipality decentralization on poverty reduction showed positive results. The study used questionnaire and interview for data collection, and considerable improvements of income increment of participants and transportation service facilitation were reported as a result of the reform.

The aforementioned studies on municipality decentralization seem to focus on how decentralization increase or decrease efficiency and effectiveness of the municipal governance with some evaluative mechanisms. However, a closer analysis and assessment of the decentralized municipal entities in the process of implementation, whether an intended functioning of municipal roles and tasks are going has not been well addressed, mainly in our context. A few of the stated research work focused solely on community participation, poverty reduction or revenue management. Based on my reading, there seems not to have been a comprehensive analysis and evaluation of municipality implementation in Ethiopian urban areas. This study, thus, focuses on assessing whether the decentralized municipality of DebreTabore has been implemented in the way it has been designed.

\section{Objectives of the Study}

The main objective of this study was to assess the implementation of decentralization in DebreTabore Municipality. More specifically, this study had the following research questions.

* What perceptions did the employees hold about the decentralized municipality implementation?

* How did provision of resources and facilities for implementation of the decentralization reform look like?

* How did the employees make decisions following the municipality decentralization?

* Were there possible relationships among the employees' perception of municipality decentralization, provision of resources and facilities and practice of decision making?

* Were there differences in responses of the participants on perception, input provision and decision making because of differences in background (e.g., gender, experience, position)?

\section{Research Methodology}

This research mainly focused on assessing the implementation of municipal decentralization in one of Amhara region town administrations. For this end, a survey research design was employed, as this design gave opportunity for addressing a large sample of individuals in a short period of time (Creswell, 2005). The research participants were some subjects selected from the individuals who were assigned and hired in the institution (Debre Tabor muncipality) for rendering administrative and management services to the public. Questionnaire (with closed ended) and semi-structured interview were employed for data collection.

\section{Participants and sampling}

This study was conducted at Debre Tabor Municipality administration located in south Gonder Zone. The municipality had about eighty thousand residents seeking administrative facilities and services. The administration of the municipality consisted of different departments such as infrastructure, service delivery, land provision, construction management, planning and greenery and investment promotion. There were 120 workers employed following the decentralized form of governance. Thus, this research involved 48 participants (40\%) out of the total population using and a mix of stratified and systematic random sampling as there were groups of workers serving in expert position, team/unit head and others. The sampling, therefore, addressed each forms of positions during the selection, and generally, this study considered 48 employees selected using stratified and simple random sampling.

\section{Data Collection Instrument}

The current research used a survey questionnaire for assessing the implementation of decentralized municipality 
of Debre Tabor. Detailed discussion on the instrument is given below.

Questionnaire

This study employed a self-reported questionnaire for addressing more participants concerning the implementation of decentralization. Using questionnaire as an instrument enables researchers to assess more individuals' performance and reflection about the things under investigation. Besides, organization and management of the collected data could be a little bit easier when participants respond their feelings or ideas in the form of closed ended items. Therefore, questionnaire was used as one of the instruments for data collection.

The questionnaire was developed based on reviews of literature on muncipality implementation and municipality roles (e.g., Cohen,etal 1999; AFTU, 2001; Ioannidis, 2015). It had two parts. The first part presented background information about the participants including gender, age, experience, education and position. The second part had a closed ended items in the form of likert scale ( strongly agree $=5$, agree $=4$, neutral $=3$, disagree $=2$ and strongly disagree $=1$ ) and frequency counts (always $=5$, usually $=4$, sometimes $=3$, rarely $=2$, and never $=1$ ) . The items were grouped into three thematic areas (perceptions on municipality decentralization (11 items example: the decentralized municipality reform help employees develop more commitment for implementing the tasks and activities(strongly agree, agree, neutral disagree and strongly disagree), decision making practices (4 items, example : I make decisions on matters that arise from customers based on my line of duties and responsibilities in the decentralized municipality - always, usually, sometimes, rarely and never) and provision of resources and facilities of decentralization implementation (4 items - example: In the decentralized municipality, the required offices are available for undertaking my duties and responsibilities -strongly agree, agree, neutral, disagree, and strongly disagree)(see appendix A).

\section{Procedures of data collection and analysis}

The prepared questionnaire was first made piloted with 20 employees and a reliability coefficient of cronbach alpha 0.76 was found. The content validity of the items were also improved with the help of not only referring literature on municipal roles and municipality decentralization implementation but also getting comments from my friends and my advisor. Thus, the desired modifications such as merging a few redundant items and replacing some vague expressions were done before distributing the final questionnaire to the participants or the employees. Then, the final questionnaire of Amharic version were administered to 50 employees or research participants by approaching one from department or units of the municipal administration. Thus, out of 50 sheets questionnaire distributed, 48 were returned filled in within two days.

Hence, the data collected from questionnaire were analyzed in the form of descriptive statistics and correlations using Statistical Packages for Social Sciences(SPSS 20) for identifying the prominent implementation results, and checking possible interrelationships among the municipal decentralization perception, input provision and decision making practice.

\section{Results}

\subsection{Questionnaire based data analysis}

Data collected through the closed ended questionnaire were analyzed in terms of background information, municipality perception, resources and facilities provision, and decision making practices. 
Table 1. Background information about the participants

\begin{tabular}{|c|c|c|c|}
\hline \multirow{4}{*}{ 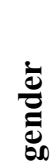 } & & frequency & Percent \\
\hline & male & 23 & 47.9 \\
\hline & female & 25 & 52.1 \\
\hline & Total & 48 & 100 \\
\hline \multirow[b]{4}{*}{ 幽 } & $18-25$ yrs & 10 & 20.8 \\
\hline & $26-40 \mathrm{yrs}$ & 28 & 58.3 \\
\hline & $41-50 \mathrm{yrs}$ & 10 & 20.8 \\
\hline & Total & 48 & 100 \\
\hline \multirow{9}{*}{ 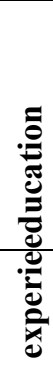 } & grade 10 or grade 12 complete & 1 & 2.1 \\
\hline & certificate & 24 & 50 \\
\hline & diploma & 19 & 39.6 \\
\hline & 1st degree & 2 & 4.2 \\
\hline & 2nd degree and above & 2 & 4.2 \\
\hline & Total & 48 & 100 \\
\hline & 2 yrs and below & 2 & 4.2 \\
\hline & $3-5 \mathrm{yrs}$ & 20 & 41.7 \\
\hline & $6-10 \mathrm{yrs}$ & 11 & 22.9 \\
\hline \multirow{2}{*}{ 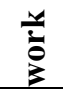 } & $11-15 \mathrm{yrs}$ & 4 & 8.3 \\
\hline & Total & 48 & 100 \\
\hline \multirow{4}{*}{ 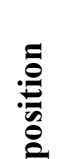 } & other & 5 & 10.4 \\
\hline & expert & 39 & 81.3 \\
\hline & dept head & 3 & 6.3 \\
\hline & Total & 48 & 100 \\
\hline
\end{tabular}

The above table 1 shows background information about the research participants. The composition of male and female participants is nearly equal (25 females and 23 males). The majority of the participants $(58.3 \%)$ are also in the middle age (26-40 yrs). Besides, significant number of the participants $(50 \%)$ has certificate level of education, while considerable amount of the participants $(39.6 \%)$ become diploma holders. Concerning work experience, relatively higher proportions of the participants $(41.7 \%)$ and $(22.9 \%)$ are merely experienced, and well experienced respectively. Furthermore, a large number of participants $(81.3 \%)$ hold the expert position.

\section{Figure 1.Perceptions of municipal decentralization}

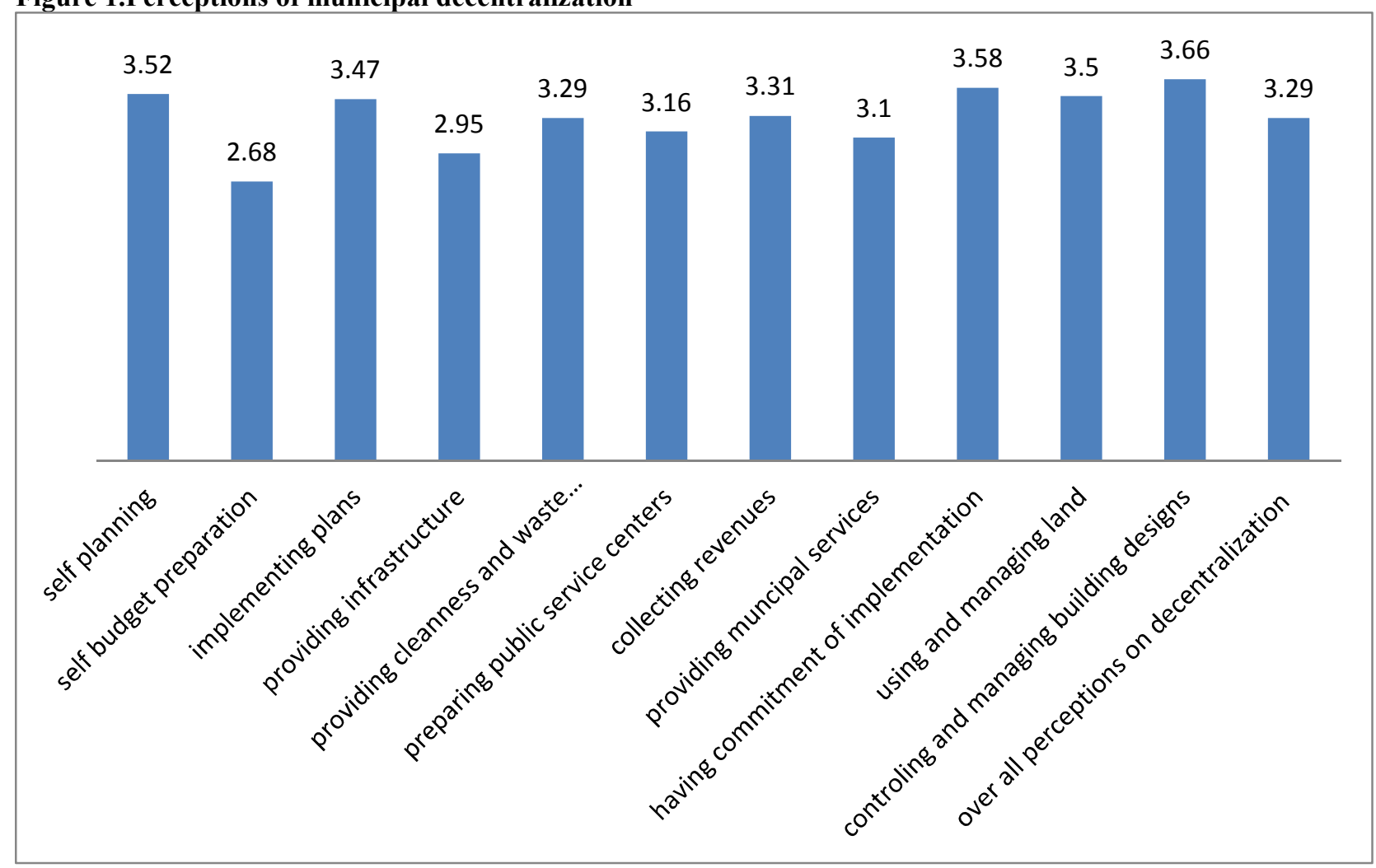


The figure above presents the participants' mean responses on individual items about municipal decentralization. The participants' responses on the four items such as controlling and managing designs, creating commitment, planning activities and using and managing urban land, and implementing plans show considerably higher perceptions (mean, $3.66 ; 3.88 ; 3.52 ; 3.50 ; 2.47$ respectively). That is, the respondents seemed to understand and acknowledge the role of municipality decentralization for empowering workers and officers in planning their own duties, managing land and building activities, having working commitments as well as implementing plans. On the remaining six items like providing municipal services, collecting revenues and preparing public service centers, the participants did not reveal their perceptions (e.g., mean, $3.10 ; 3.31 ; \& 3.16$ respectively). In other words, the participants did not appear to be clear about the decentralization reform mainly on such items mentioned. The overall perception the participants hold about the municipal decentralization does not reveal noticeable degree of perceptions and acknowledge (mean, 3.29). They seemed to be neutral or no reaction on the reform of municipality decentralization. However, the interview result tends to contradict this survey data in that all except one of the interviewees understood the decentralized municipality and had a reasonable level of acknowledgement of its roles (see section 4.1.1).

Figure 2. Provision of resources and facilities for municipal decentralization

\begin{tabular}{|ccccc|}
\hline 3 & 3.04 & 3 & 2.91 \\
\hline 2.62 & & & \\
& & & \\
\hline $\begin{array}{c}\text { budget release for } \\
\text { implementation }\end{array}$ & office arrangement & $\begin{array}{c}\text { provision of office } \\
\text { facilities and } \\
\text { materials }\end{array}$ & $\begin{array}{c}\text { provision of } \\
\text { materials for } \\
\text { implementation }\end{array}$ & $\begin{array}{c}\text { over all resources } \\
\text { and facilities } \\
\text { provisions }\end{array}$ \\
\hline
\end{tabular}

Figure 2 above indicates the participants' responses on the existing provision of resources and facilities following the municipal decentralization. The respondents did not react on the three items concerning office arrangement, facilities and materials provision (mean, $3.00 ; 3.04 \& 3.00$ respectively). That is, the participants did not seem to acknowledge or reject the existing inputs provision for municipal implementation. The participants' response on the overall resources and facilities provision also indicate undecided (mean, 2.91). However, concerning the required budget, they seem to disagree on the provision (mean, 2.61). Generally, the participants did not appear to speak out about the resources and material provisions needed for municipal implementation. This result seemed to contract to the interview data that all of the respondents acknowledged positively the existing provisions of resources and facilities (see section 4.1.2).

\section{Figure 3.Decision making practices}

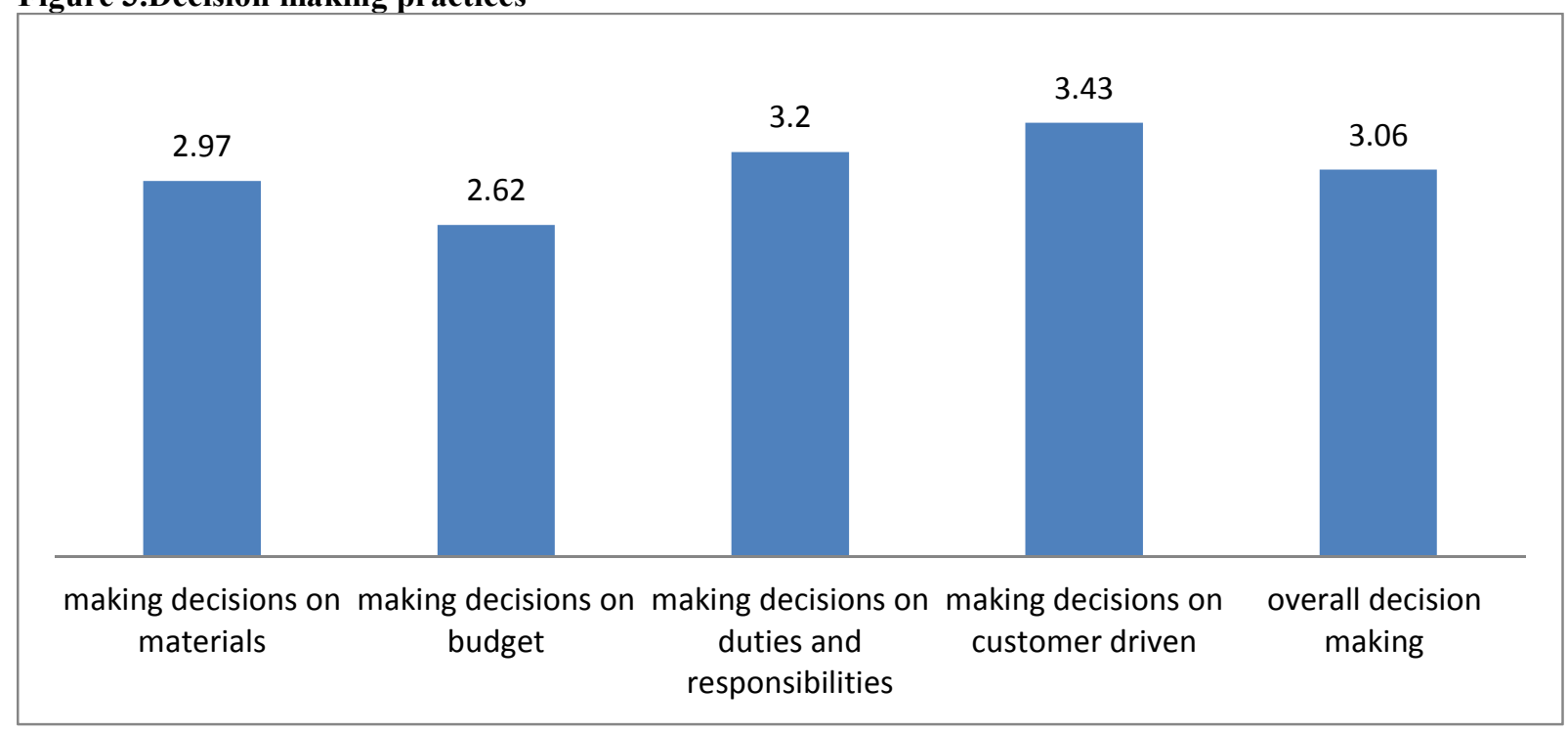

The above figure 3 presents the participants' mean responses on decision making practices following the 
municipal decentralization process. The respondents' decision making practices become considerably significant mainly on three issues such as customer driven, duties and responsibilities, and working materials (mean 3.43; $3.20 ; \& 2.97$ respectively). That is, the participants' tend to show more decision making practices on important such important issues. The overall decision making practice also indicates considerably good level (mean, 3.06). Conversely, the participants do not reveal fair amount of decision making effort on budget utilization and management (mean, 2.62). Interview data, however, disconfirmed such fair level of decision making practices that the survey participants reported here. That is, four of the interviewees noted considerable gaps on decision making practices mainly because of frustration and insincerity (see section 4.1.3).

\subsection{Background differences in municipal perceptions, resources and facilities provision and decision making practices}

The possible differences in response to municipality decentralization in terms of gender, education, work experience and position have been presented one by one.

Figure 4.Gender difference in municipal decentralization perceptions, resources and facilities provision and decision making practices

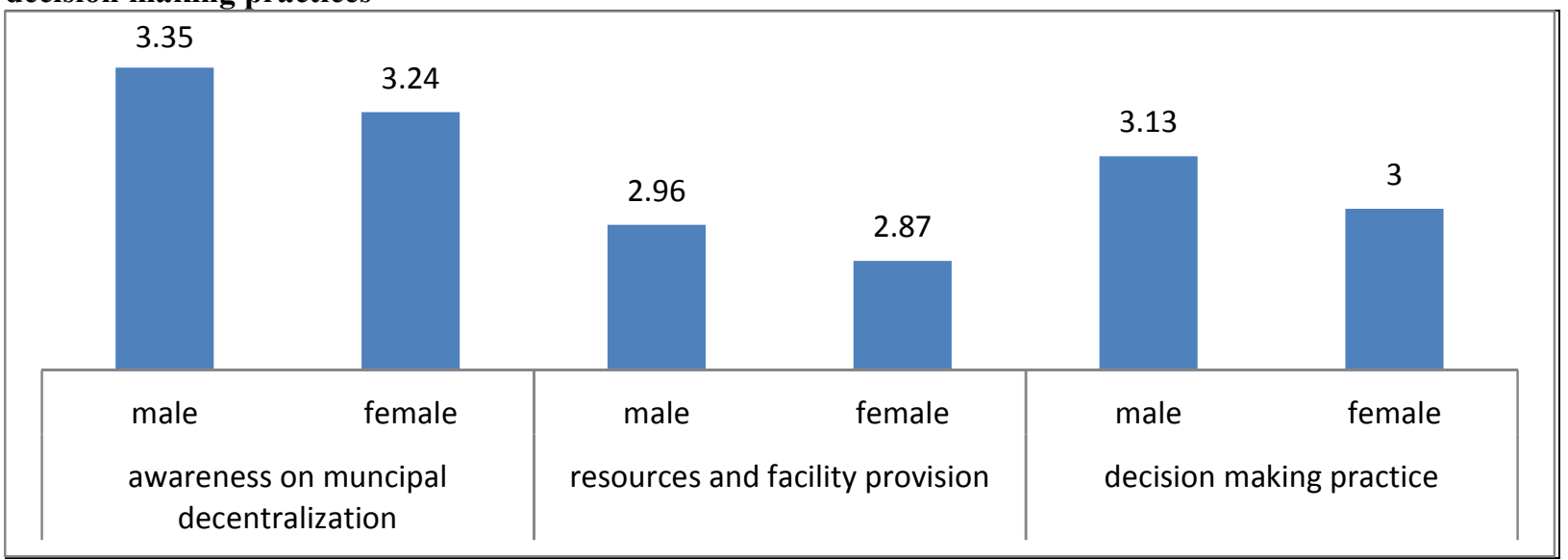

Figure 4 above shows mean response differences on municipal decentralization perception, resources and facilities provision and decision making practice between male and female participants. Males' mean responses on the three areas like awareness on municipality decentralization, resource and facility provision, and decision making are fairly greater than that of females (e.g., mean, $3.35 ; \& 3.24$ for males and females respectively). That is, male participants seemed to reveal more perceptions, resource and facilities provision acknowledgements as well as decision making practices as compared to the female participants'.

Figure 5. Differences in education with municipal decentralization perceptions, resources and facilities provisions and decision making practices

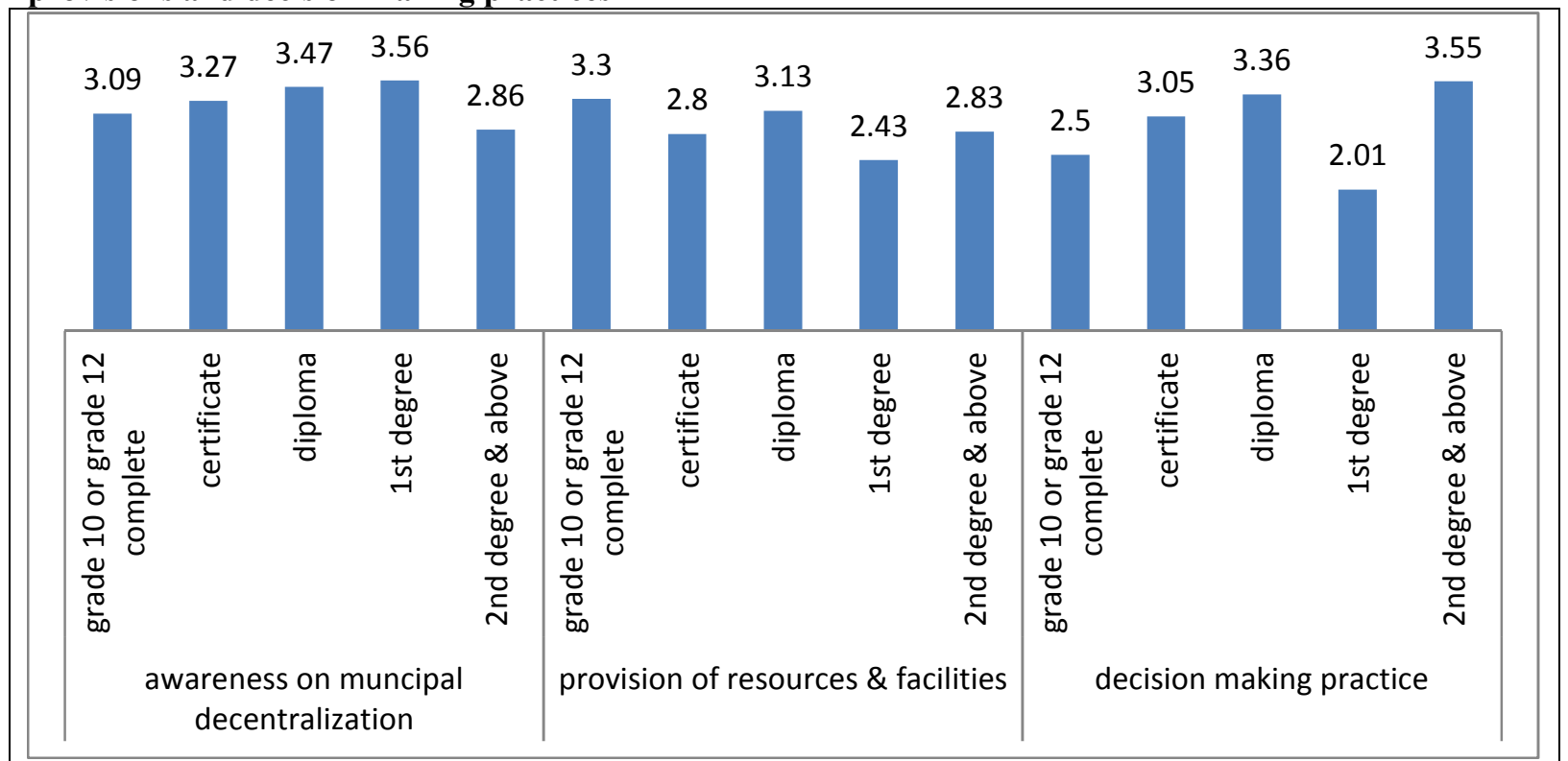

The above figure presents mean responses based on education differences starting from grade 10 or grade 12 
complete to $2^{\text {nd }}$ degree and above. As compared to other participants' education levels, the participants having first degree and diploma show greater mean responses on their municipal decentralization perception (mean, 3.56; \& 3.47 respectively). That is, more awareness about the municipal decentralization tends to be revealed on degree and diploma holders of the participants. Concerning provision of resources and facilities, certificate and first degree holder participants showed lower mean responses as compared to others' (mean $2.80 \& 2.43$ respectively). In other words, these groups of participants seemed to be dissatisfied with the existing resources and facilities provision while the remaining parts of the participants quiet not sure of the provision. In decision making practice, the three groups of participants such as participants with $2^{\text {nd }}$ degree and above, diploma and certificate showed fairly high decision making practices (mean, $3.55 ; 3.36 \& 3.05$ respectively). In general, differences in education tend to reveal mere variations in municipal decentralization perception, resource and facilities provision and decision making practices.

Figure 6. Differences in work experience in municipal decentralization perceptions, resources and facilities provisions and decision making practices

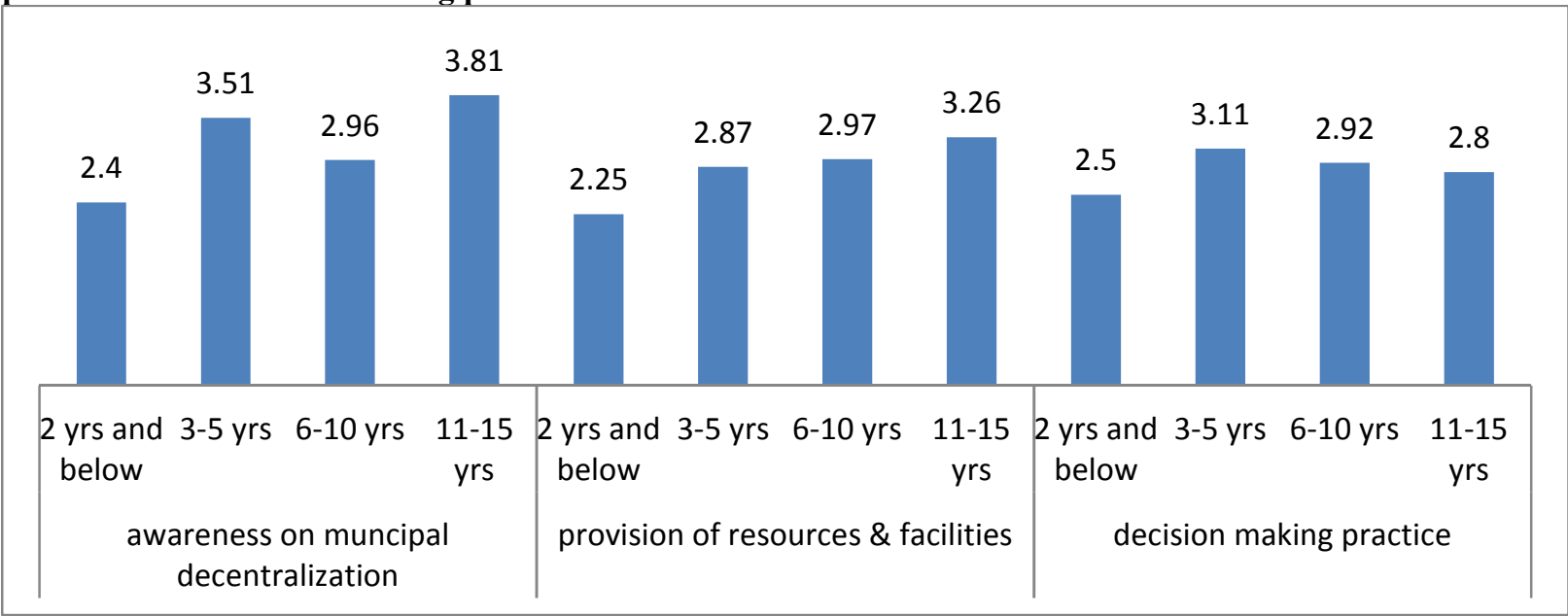

The figure above shows mean responses on decentralization perception, resource and facilities provision and decision making practices against work experiences. The highest work experience group of participants (11-15 yrs) indicates high level of understanding about municipal decentralization, while the least experienced ones (2rs and below) are having lower awareness (mean, $3.81 ; \& 2.40$ respectively). The participants' response on provision of resources and facilities becomes merely unanimous for all age groups except the youngster group (2yrs and below) that showed lower mean response (mean, 2.25). Similarly, the participants on decision making practice indicate fairly similar mean response except youngsters (2yrs and below) that has minimum mean response (mean, 2.50). Generally, differences in work experience did not reveal more variations of response on provision of resources and facilities, and decision making practice, while considerable mean differences of response observed on municipality decentralization perception.

Figure 7. Differences in position in municipal decentralization perceptions, resources and facilities provisions and decision making practices

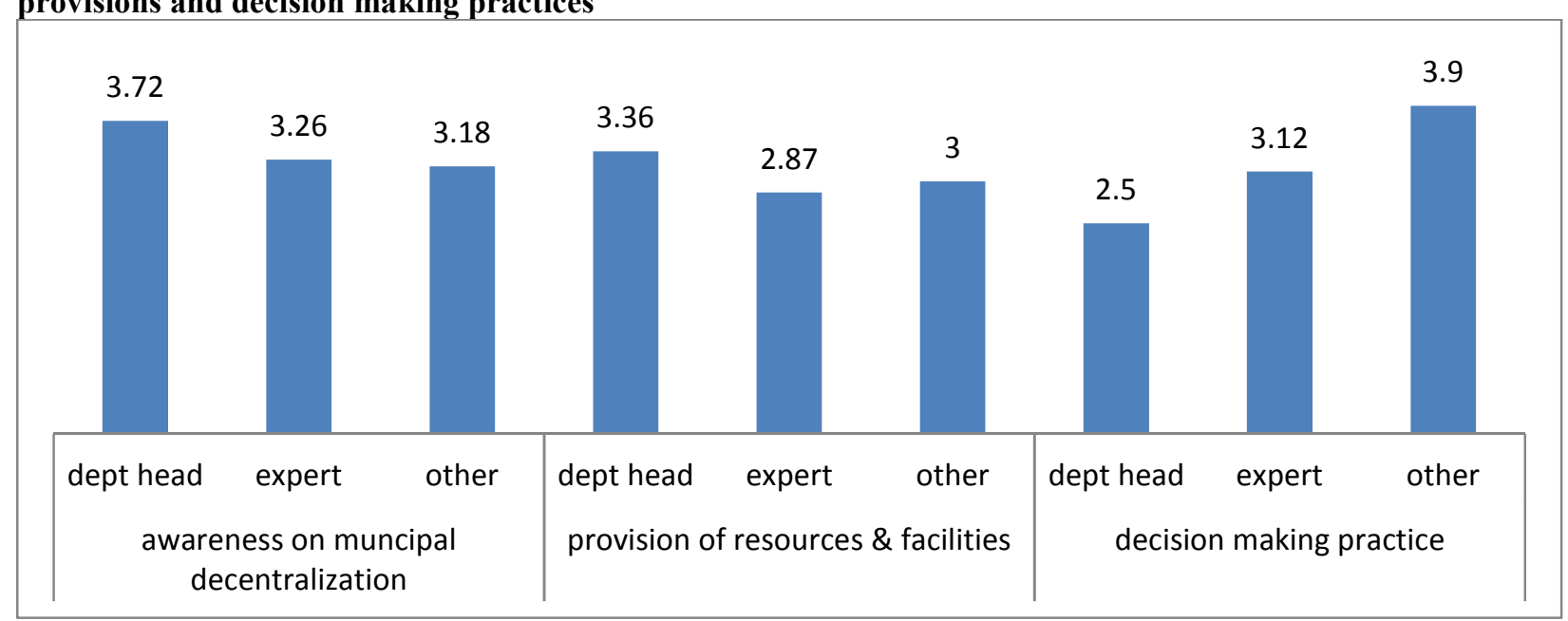

Figure 7 above shows mean responses on municipal decentralization perception, resource and facilities provision, and decision making practices based on position levels. A greater mean response is observed on 
awareness of municipal decentralization for department heads while fairly similar level of mean responses are there for expert and other positions(mean, 3.72; $3.26 \& 3.18$ respectively). Similarly, department head group of participants indicate higher mean response on provision of resources and facility compared to the two positions' (mean, 3.36; $2.87 \& 3.00$ respectively). On decision making practices, considerable variations of mean responses are observed among depart head, expert and other (mean, 2.50; $3.12 \& 3.90$ respectively). Generally, differences in mean responses on municipal decentralization perception, resource and facility provision and decision making practice based on position differences seem to be considerably varied on responses of decision making though higher mean response on perception about municipal decentralization is seen for department head position.

Table 2.Correlations among awareness, provision of resource and facility and decision making practice

\begin{tabular}{|c|c|c|c|c|c|}
\hline & & $\begin{array}{l}\text { awareness on } \\
\text { municipal } \\
\text { decentralization }\end{array}$ & $\begin{array}{l}\text { resources and } \\
\text { facility } \\
\text { provision }\end{array}$ & $\begin{array}{l}\text { decision } \\
\text { practice }\end{array}$ & making \\
\hline $\begin{array}{l}\text { awareness on } \\
\text { municipal } \\
\text { decentralization }\end{array}$ & & & & & \\
\hline $\begin{array}{l}\text { Provision } \\
\text { resources } \\
\text { facilities }\end{array}$ & $\begin{array}{l}\text { Corr. } \\
\text { Sig. (2-tailed) }\end{array}$ & $\begin{array}{l}.469^{* *} \\
0.001\end{array}$ & & & \\
\hline $\begin{array}{l}\text { decision making } \\
\text { practice }\end{array}$ & $\begin{array}{l}\text { Corr. } \\
\text { Sig. (2-tailed) }\end{array}$ & $\begin{array}{l}.388^{* *} \\
0.006\end{array}$ & $\begin{array}{l}.349^{*} \\
0.015\end{array}$ & & \\
\hline
\end{tabular}

\section{**. Correlation is significant at the 0.01 level (2-tailed).}

\section{. Correlation is significant at the 0.05 level (2-tailed).}

Table 2 above presents correlation coefficients among municipal decentralization perception, resource and facility provision and decision making practice. The data show statistically significant positive correlations among the three areas such as awareness of municipality decentralization, provision of resource and facility and practice of decision making (corr. $0.469 ; 0.388 \& 0.349$, respectively where $\mathrm{p}<0.05$ ). This implies that the more awareness about municipality decentralization as well as more provisions of resource and facility, the higher the practice of decision making. In other words, fairly strong positive interrelationship seemed to exist among the three variables, i.e. municipality perception, input provision and decision making. Making some form of improvement one of the focused areas (perception on municipal decentralization, decision making practice and in provisions) would mean considerable changes on the remaining variables in a positive manner.

\section{Discussion}

The results of this study on the perceptions about the municipality decentralization implementation seemed to be fairly considerable. Evidences from interview data and a few responses of the survey appeared to reveal that the participants acknowledged substantially about the relevance of the decentralized municipality for good governance. This result tends to contract Ioannidis's (2015) study findings at Greek, where a substantial degree of dissatisfaction on the municipality decentralization reform was observed in the institutional actors.

Concerning the input provisions for implementation, the survey result did not reveal substantial evidence for the quantity and quality of the provision though reasonable amount of positive evidences were found from the interview data. Therefore, the theoretical assumption that claims decentralization improves the efficiency and effectiveness of resource management and utilization (Horn, 1995 and Gibbons, 1998 as cited in Casasnovas, McDaid and Costa-front, 2009;Gaulle, 2010) tends to be slightly supported with this finding.

Meanwhile, the decision making problems shown from this study seemed to contradict with the commonly assumed criticism that decentralization may create space for corrupting local actors by abusing their authorities (Crook and Manor, 1998). Nevertheless, the positive correlations among municipal decentralization, input provision and decision making practice of this research finding, seemed to correspond with the theoretical argument that claims the awareness of policy implementation, and the higher provision of resources would produce more effective implementation practices (Ostaaijen, 2008; Lameck, 2011).

\section{Summary and Conclusions}

Based on the survey data, the overall perceptions about the role of the municipal decentralization, appeared to be not significant though considerable level of understanding and acknowledging observed in four areas (controlling and managing designs, creating commitment, planning activities and using and managing urban land, and implementing plans) (see figure 1). Nevertheless, noticeable understanding and acknowledgement of the municipality's decentralization positive roles was revealed from the responses of the interviewees (see section 
4.1.1). Concerning provision of inputs for the decentralization, the survey participants did not appear to respond on the quantity and qualities of resources and facilities provided though compelling evidences were generated from interview results that input provision has not been a question for employees in performing their duties and responsibilities. The survey data on decision making practices tends to reveal fair level of performance (see figure 3 ) though the data from interview failed to confirm it (see section 4.1.3). Besides, based on the data from questionnaire, considerably significant positive interrelationships were seen among the participants' municipality decentralization perception, input provision and decision making practice (see table 2). On course, there seemed not to find evidences for such interrelatedness from interview data.

Generally, the results of the survey and the interview could indicate four points. First, municipality decentralization perceptions were fairly noticeable on the participants but not significant. Secondly, the provision of inputs for the municipality decentralization did not appear to be recognized. Thirdly, decision making practices did not reveal significantly in the municipality decentralization. Lastly, not least, positive interrelationships seemed to be observed among the participants' municipal decentralization perception, provision of inputs and decision making practices.

Based on the aforementioned summary of results, the following conclusions are forwarded.

1. Considerable level of perceptions about the promises of municipal decentralization seemed to be seen on the participants. The survey data mainly on four issues of decentralization, revealed significant degree of understanding and acknowledgement of the positive roles decentralization could play in the municipality administration.

2. Provision of inputs for the municipal decentralization implementation appeared to be not concerned by the participants. The survey data did not reveal the positions of the participants either acknowledging the provision or not.

3. Decision making practices did revealed significantly following the municipal decentralization implementation. Although fair level of decision making practices revealed in the survey data, a large number decision making occasions did not seem to have finalized.

4. There seemed to have positive relationships among the participants' perceptions about municipality decentralization, input provision and practice of decision making. The survey correlation results showed this clearly.

5. There seemed to have descriptive variations of responses to municipal decentralization perceptions, in provision and decision making among the participants based on their background differences (gender, position, and experience).

\section{References}

AdonayHabtu Belay (2011). Popular participation in decentralized governance . (With special emphasis in AdiHaki local administration, Mekele city). Unpublished MA thesis. Mekele University.

Burns D. (1994). The politics of decentralization. London. The MacMillan press Ltd.

Ebel R. D. and Yilmaz S. (2001). concept of fiscal decentralization and worldwide overview. International Symposium Québec Commission on Fiscal Imbalance Québec City, Québec September 13 and 14,

Falleti T. G. (2005). Sequential Theory of Decentralization: Latin American Cases in Comparative Perspective. American Political Science Review Vol. 99, No. 3 August 2005, University of Pennsylvania

Gaule E. (2010). Public governance decentralization modeling in the context of reforms. public policy and administration. Vol. 32, p. 47-60

Gemechu, Mulugeta Debebe (2007). Emergency Aid and Sustainable Rural Livelihood: The Case of ShaladGoto, (Master's Thesis-unprinted), Addis Ababa University

Gregory A (1992). "Evaluation methodologies - A system for use."Oper. Res. Soc., 43(1).

Habtamu Atlaw \& Sied Mohammed (2014). The Role of Urban Municipality Decentralization in Reducing Urban Poverty in Ethiopian Somali Region: The Case of Jigjiga and Gode Towns. International journal of innovative research and development vol. 3 , issue 9 .

Ioannidis P. (2015). Decentralization, Local Government Reforms and Perceptions of Local Actors: The Greek Case

Jamo, Shiferaw (2005). Fiscal Federalism in Ethiopia: The Current Perspective. Addis Ababa [unpublished].

Klugman, J (1994) 'Decentralization: A Survey of Literature from a Human Development Perspective', pp. 4-16, New York: UNDP

Kröger T. (1997). The Dilemma of Municipalities: Scandinavian Approaches to Child. Jnl Soc. Pol., 26, 4, 485507.

Lameck, W., U. (2011).Strengthening intra municipal decentralization through physical accessibility of services and openness in service delivery: The case of Morogoro municipal Council. Journal of Public Administration and Policy Research Vol. 3(5) pp. 141-155.

Manor, J., (1998).The Political Economy of Democratic Decentralization, Washington D.C.: World Bank. 
Merera Gudina (2007). Ethnicity, Democratization and Decentralization in Ethiopia: The Case of Oromia. Eastern Africa Social Science Research Review, Vol. 23, No. 1. pp. 81-106.

Negussie, Solomon (2008). Fiscal Federalism in the Ethiopian Ethnic Based Federal System. The Netherlands: Wolf Legal Publishers

Oates, W. 1968."The Theory of Public Finance in a Federal System.” Canadian Journal of Economics, I, No.1.

Ostaaijen JV (2008). "The added value for intra Municipal decentralization: The comparison of Bologna, Rotterdam and Birmingham." Draft version.

Oxfam GB (2005). The Implementation of the Decentralization Policy in Ethiopia. Addis Ababa: Oxfam GB

Ribot J. C., 2004, Waiting For Democracy: The Politics of Choice in Natural Resource Decentralization, World Resources Institute paper, Washington D.C.: World Resources Institute.

2002, African Decentralization: Local Actors, Powers and Accountability, UNRISD Programme on Democracy, Governance and Human Rights Paper 8, Geneva: UNRISD.

Robertson B., (2002). Overview of decentralization worldwide. International Conference on Decentralization Federalism, The Future of decentralising states, Manila, Philipines.

Rondinelli D.A., McCullough, J. S., Johnson, R. W. (1989). Analyzing Decentralization Policies in Developing Countries: A Political Economy Framework. In Development and Change, Vol. 20, Issue 1, pages 57-87, January 1989

Tegegne Gebre Egziabher (1998). The influence of decentralization on some aspects of local and regional development planning in ethiopia. EASSRR, vol. xiv, no. 1.

Tegenu Tsegaye (2006). Evaluation of the Operation and Performance of Ethnic Decentralization System in Ethiopia: A Case Study of the Gurage People (1992-2000). Addis Ababa: Addis Ababa University Press

Thede, N., (2008), 'Decentralization, Democracy and Human Rights: A Human Rights-based Analysis of the Impact of Local Democratic Reforms on Development', Journal of Human Development (forthcoming)

Turner, M (1999) 'Central-Local Relations: Themes and Issues', in M Turner (ed.) Central-Local Relations in Asia-Pacific: Convergence or Divergence? London and New York: Macmillan and St Martin's.

USAID (2009). Democratic Decentralization Programming Handbook. Washington: ARD. Inc. 